\title{
LEPTIN AND ITS MECHANISM OF ACTION
}

\section{LEPTIN I MEHANIZAM DELOVANJA LEPTINA}

\author{
Anastasija Panić, Sanja Soskić, Esma R. Isenovic',2,3
}

\section{Summary}

Leptin is a hormone produced by the adipose tissue, which has effects on the central nervous system. Leptin is bound to its Ob receptor on hypothalamic neurons to inhibit feeding behavior and to increase sympathetically - mediated thermogenesis. In addition to anorexia and thermogenesis, leptin also has direct peripheral and central nervous system - mediated effects on the endocrine, vascular, hematopoietc, immune and musculoskeletal systems. Leptin accomplishes its effects using distributed network of leptin receptors and differential molecular signaling pathways. Leptinemia is increased in obesity because of increased adipocyte mass, but obese subjects exhibit resistance to the anorexic and metabolic effects of leptin. However, multiple studies have shown that leptin can increase sympathetic nerve activity to non - thermogenic tissues in rodents causing obesity related hypertension. One potential explanation of this paradox is selective leptin resistance. Compared with large and persuasive number of studies on the sympathetic and blood pressure effects of leptin in experimental animals, relatively little attention was given to these effects of leptin in humans. This review article presents recent findings related to leptin and its mechanism of action, and also the role of leptin in patophysiological conditions.

Key words: leptin, hypothalamus, molecular signaling, obesity, (selective) leptin resistance, obesity - induced hypertension.

\section{Sažetak}

Leptin je hormon adipoznog tkiva koji svoje efekte ostvaruje delovanjem na centralni nervni sistem. Leptin se vezuje za svoje OB receptore na neuronima hipotalamusa i posledično suprimira unos hrane i povećava aktivnost simpatičkog nervnog sistema čime stimuliše proces termogeneze i potrošnje energije. Osim što suprimira apetit i stimuliše termogenu potrošnju energije, leptin ostvaruje svoje efekte i na druge organske sisteme, kao što su endokrini, vaskularni, hematopoetski, imunski i mišínoskeletni, delujući bilo direktno na periferiji organizma, bilo posredstvom centralnog nervnog sistema. Svoje efekte leptin ostvaruje putem veoma rasprostranjene mreže leptinskih receptora, preko nekoliko različitih molekularnih signalnih puteva. Stanje gojaznosti je praćeno povećanjem nivoa leptina u cirkulaciji usled povećane količine masnog tkiva, ali i pored toga, gojazne osobe ispoljavaju rezistenciju na anoreksigenične i metaboličke efekte leptina. Izvestan broj studija je pokazao da leptin može povećati aktivnost simpatičkog nervnog sistema i u netermogenim tkivima glodara dovodeći do hipertenzije usled gojaznosti. Koncept selektivne rezistenicije na leptin predstavlja moguće objašnjenje ovog paradoksa. Još uvek su malobrojne studije u kojima je ispitivan fenomen selektivne leptinske rezistencije kod ljudi. U okviru ovog preglednog članka, dat je prikaz najnovijih saznanja o leptinu, mehanizmu njegovog delovanja kao i o ulozi leptina u patofiziološkim stanjima.

Ključne reči: leptin, hipotalamus, molekularna signalizacija, gojaznost, rezistencija na leptin, gojaznošću indukovana hipertenzija

LEPTIN - OPŠTE OSOBINE I EFEKTI DELOVANJA LEPTINA

Za otkriće hormona leptina (na grčkom leptos znači mršav), Coleman-u i Friedman-u je dodeljena nagrada (engl. Albert Lasker Basic Medical Research Award) 2010. godine [1]. Leptin je hormon adipocita koji šalje informaciju mozgu o statusu energetskog balansa u perifernim tkivima organizma [2] [3] [4].

Efekti leptina na hipotalamus zavise od prisustva receptora za leptin [1]. Fei i saradnici su, koristeći tehniku reakcije lančane polimeraze (PCR, engl. polymerase chain reaction), otkrili $\mathrm{OB}-\mathrm{Rb}$, jedan od receptora koji je odgovoran za $d b$ fenotip i koji se eksprimira u nucleus arcuatus -u (ARC), ventromedijalnom (VMH), dorzomedijalnom $(\mathrm{DMH})$ i lateralnom ( $\mathrm{LH})$ hipotalamusnom nukleusu, dok OB-Rb nije detektovan u drugim delovima mozga [5]. Studije na lezijama kod pacova (u nekim slučajevima i humanim) pokazali su prekide u nukleusima ARC, VMH i DMH što rezultuje hiperfagijom i gojaznošću [6-9], dok lezije u LH nukleusu dovode do hipofagije [10]. Model dvojnog centra označava VMH nukleus kao "centar za sitost" i LH nukleus kao "centar za glad" [11]. Fei i saradnici su, svojim istraživanjima, ukazali na dominantnu ulogu signalizacije leptina u centralnoj regulaciji energetskog balansa [5, 12-14]. Ubrzo nakon otkrića gena $o b$, Stephens i saradnici su pokazali da leptin reguliše unošenje hrane i metabolizam delom preko inhibicije sinteze i oslobađanja neuropeptida Y (NPY), koji stimuliše unošenje hrane i smanjuje termogenezu [15].

Kasnije studije su pokazale da leptin inhibira neuralne puteve koji stimulišu unošenje hrane (oreksigenični) i smanjuje potrošnju energije, $i$ isto tako aktivira neuralne puteve koji inhibiraju unošenje hrane (anoreksogenični) $[4,16,17]$. Oreksigenični neuropeptidi uključuju NPY i Agouti-sličan peptid (AgRP), dok anoreksogenični signali sadrže $\alpha$-melanokortin-stimulišući hormon ( $\alpha-M S H$, produkti POMC) [1]. Neuroni koji su označeni kao AgRP ili POMC i neuroni koji eksprimiraju melanokortinske receptore (MCR) obuhvataju sistem melanokortina koji reguliše energetski balans $[16,17]$. 
Atraktivan i jednostavan model koji pokazuje interakciju između signalizacije leptina i centralne regulacije unošenja hrane može se opisati na sledeći način: leptin aktivira neurone POMC preko "firing rates" i genske ekspresije; aktivirani neuroni POMC oslobađaju a-MSH u sinapse što aktivira neurone preko vezivanja za MCR i dovodi do anoreksigeničnih odgovora povećanja potrošnje energije [1]. Istovremeno, leptin inhibira neurone NPY/AgRP poništavajući antagonistički efekat AgRP na MCR (Slika 1.) $[18,19]$. Neuroni NPY/AgRP stimulišu oreksigenične odgovore preko direktne sinapse [20,21]. Nepostojanje povratne sprege između neurona POMC do neurona NPY/AgRP ukazuje da je nedostatak funkcije neuronskog kruga da potpomaže unošenje hrane [16, 17]. Značajnost sistema melanokortina je pokazana ne samo time što leptin direktno deluje na krug u hipotalamusu, već $\mathrm{i}$ činjenicom da je gubitak funkcije MC-4R, glavnog MCR, najčešći genetički uzrok gojaznosti kod ljudi i kreće se od $3-5 \%$ visoke gojaznosti kod ljudi $[22,23]$. Ukratko, leptin reguliše energetski balans moduliranjem aktivnosti i genske ekspresije neurona NPY/AgRP i neurona POMC u nukleusu ARC [1]. Pinto i saradnici su otkrili još jedan nivo regulacije energetskog balansa identifikujući brzo obnavljanje neuralnog kruga ARC nukleusa pomoću leptina [24]. Sinapse projektovane na neurone NPY/AgRP i POMC bile su različite kod ob/ob miševa i kod "wild type" miševa [1]. Tretiranje leptinom je normalizovalo gustinu sinapsi tokom šest sati, nekoliko sati pre efekta leptina na unošenje hrane [1]. Ova otkrića ukazuju na to da leptin deluje na hipotalamus i preko neuralne plastičnosti [1].

Slika 1. Regulacija apetita od strane leptina delovanjem na nucleus arcuatus hipotalamusa

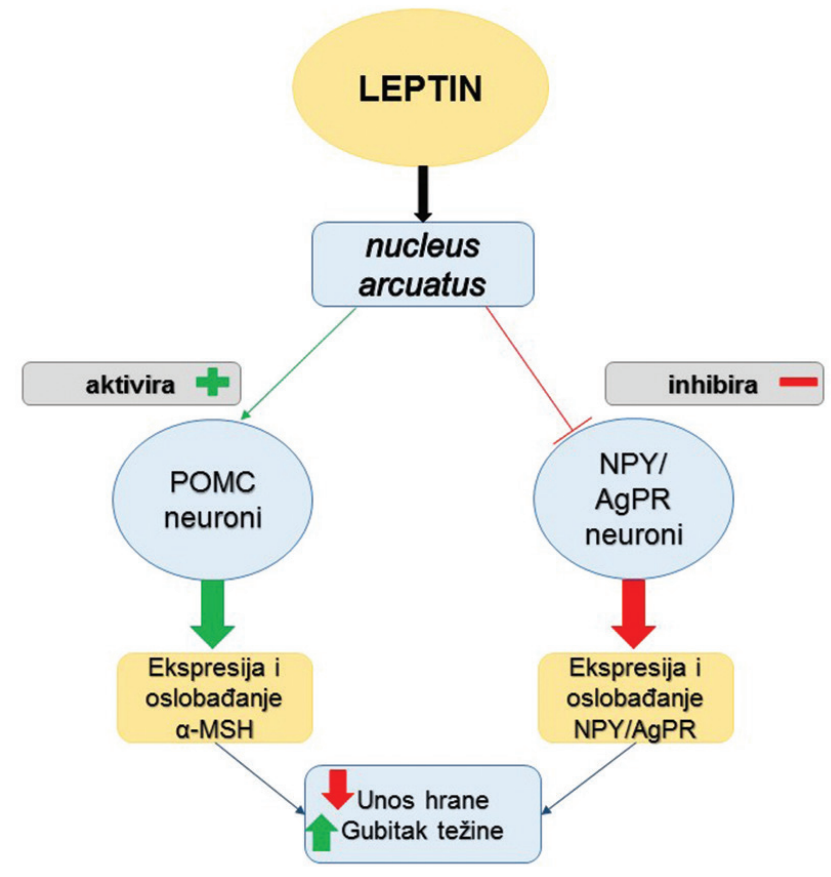

POMC - proopiomelanokortin (engl. proopiomelanocortin), NPY neuropeptid Y (engl. neuropeptide Y), AgRP - peptid „srodan“ aguti proteinu (engl. agouti-related peptide), a-MSH - alfa-melanocitstimulišući hormon (engl. alpha-melanocyte-stimulating hormone).

\section{Protein leptin}

Protein ob (protein leptin) se kao monomer "pakuje" u heksagonalnu kristalnu formu [25]. Protein leptin čine četiri antiparalelna $\alpha$-heliksa (A, B, C i D) povezana pomoću dve duge ukrštajuće veze $(\mathrm{AB}$ i $\mathrm{CD})$ i jednom kratkom petljom $(\mathrm{BC})$ raspoređena tako da čine ulevo izuvijani spiralni paket [25]. Četiri $\alpha$-heliksa čine sledeći ostaci: A, Pro 2-His 26; B, Leu 51-Ser 67; C, Arg 71Lys 94; D, Ser 120-Ser 143 [25]. Humani protein leptin dužine je $167 \mathrm{AK}$ i težine $16 \mathrm{kDa}$ [26]. Ispitivanja strukturne sličnosti otkrivaju da protein leptin pokazuje najveću strukturnu sličnost sa citokinima familije IL-6 i G-CSF i u manjem stepenu sa drugim citokinima dugog lanca uključujući GH i laktogen iz placente [27-29].

\section{RECEPTORI ZA LEPTIN}

Plejotropna dejstva leptina omogućena su univerzalnom distribucijom OB-R receptora za leptin [30]. Leptin deluje preko transmembranskih receptora koji pokazuju strukturnu sličnost sa klasom i familije receptora za citokine [31-35], što uključuje receptore za IL-2 (interleukin-2), IL-3, IL-4, IL-6, IL-7, LIF (inhibitorni faktor leukemije), stimulirajući faktor kolonije granulocita (G-CSF), hormon rasta $(\mathrm{GH})$, prolaktin i eritropoetin $[36,37]$. Članovi ove familije imaju karakteristične ekstracelularne motive i četiri ostatka cisteina i WSXWS (Trp-Ser-Xaa-Trp-Ser) [38] sadržeći različit broj domena fibronektina tipa III $[39,40]$. Receptor za leptin OB-R nastaje u formi nekoliko alternativno iskrojenih (splajsovanih) varijanti označenih kao OB-Ra, OB-Rb, OB-Rc, OB-Rd, OB-Re i OBRf [32, 41], koji imaju zajednički ekstracelularni domen od preko 800 amino kiselina (AK), transmembranski domen od $34 \mathrm{AK}$ i varijabilni intracelularni domen koji je karakterističan za svaku od izoformi receptora za leptin [30]. Na taj način, izoforme se klasifikuju u tri klase: kratku, dugu i sekretujuću izoformu [30].

TranSDUKCIJA SIgNALA POD DELOVANJEM LEPTINA

Leptin je kao multifuncionalni citokin prisutan u svim tkivima i uključen je u brojne ćelijske funkcije u celom organizmu [30]. Da bi ostvario sva svoja dejstva leptin interaguje sa mnogim signalnim faktorima ukrštajući se sa različitim putevima signalne transdukcije preko svojih receptora [30].

Nakon vezivanja leptina za OB-R, koji se prvenstveno nalazi u hipotalamusu, receptor prolazi kroz proces promene konformacije, što dovodi do aktivacije Janus kinase 2 (JAK2) unutar ćelije, i posledične fosforilacije proteina transduktora signala i aktivatora transkripcije proteina tip 3 (engl. Signal transducer and activator of transcription protein type 3, STAT3) [42]. Fosforilisani STAT3 formira homodimer i vezuje se za nuklearne promoterske regione [42]. Osim JAK-STAT signalnog 
puta, vezivanje leptina za OB-R takođe aktivira signalne kaskade fosfoinozitol 3 kinaze (engl. phosphoinositol 3 kinase, PI3K) [43] i mitogenom aktiviranih protein kinaza/vanćelijskim signalima regulisanih kinaza (engl. mitogen-activated protein kinases/extracellular signalregulated kinases, MAPK/ERK) [44]. Aktivacija svakog od ovih puteva doprinosi anoreksigeničnim efektima leptina, odnosno suprimiranju apetita, podsticanju gubitka telesne mase, i povećanju termogeneze [43-45].

Članovi kinaze regulisane vanćelijskim signalom (ERK) koji pripadaju familiji MAPK su komponente dobro definisanog signalnog puta Ras/Raf/MAPK i aktiviraju se širokim opsegom stimulusa uključujući i leptin [30]. Put MAPK može biti stimulisan bilo OB-Ra ili OB-Rb, iako $\mathrm{u}$ manjem stepenu ovim drugim [46, 47]. Iako distalni deo OB-R nije esencijalan za signalizaciju MAPK, intaktni intracelularni deo duge forme receptora je potreban da bi se postigla maksimalna aktivacija [30]. Ovo se bazira na činjenici da leptin može biti "okidač" kaskade MAPK na dva različita načina: fosforilacijom tirozina sa aktivacijom asociranog receptora za JAK2 ili nezavisno od fosforilacije receptora $[37,46]$. U oba slučaja nishodna signalizacija zahteva prisustvo intaktnog katalitičkog domena, domena homologije slične Src koji sadrži protein tirozin fosfatazu (SHP-2 domena) [30]. Nedostatak aktivnosti fosfataze uzrokuje nedostatak fosforilacije ERK [48]. Iako još nije u potpunosti rasvetljeno koji su molekuli uključeni u transmisiju signalizacije leptina, aktivirane kinaze MAPK/ERK (MEK kinaze) fosforilišu ERK dovodeći do ekspresije $c$-fos i egr-1 koji učestvuju u ćelijskoj proliferaciji i diferencijaciji [30].

\section{REZISTENCIJA NA LEPTIN}

Termin "rezistencija na leptin" nastao je nedugo po otkriću hormona leptina 1994. godine [49-51]. Koncept rezistencije na leptin podrazumeva da procesi koji izazivaju i/ili rezultuju iz stanja gojaznosti narušavaju efekte leptina i time olakšavaju nastanak gojaznosti kao i ometanje potencijalne efikasnosti terapije primenom egzogenog leptina [51]. Tako je razumevanje mehanizama koji mogu biti u osnovi rezistencije na leptin bitno za determinisanje uzroka gojaznosti i identifikovanje mogućih mehanizama na koje se može delovati terapijom [51].

Koncept selektivne rezistencije na leptin (engl. selective leptin resistance, SLR) i njegove potencijalne posledice po gojaznost i hipertenziju bazira se na tome da u stanju gojaznosti postoji rezistencija na efekte leptina na apetit, kao i na redukciju telesne težine, ali su očuvani efekti leptina na simpatički nervni sistem [51]. Ova pojava može delimično objasniti kako hiperleptinemija može pratiti gojaznost (delimični gubitak apetita i metaboličkih dejstava leptina), ali takođe i doprineti prekomernoj simpatičkoj aktivnosti i hipertenziji, očuvanjem simpatičkih dejstava leptina [51].
Pokazano je da Aguti žuti gojazni miševi imaju mutaciju u genu za aguti protein što dovodi do sveprisutne prekomerne ekspresije aguti proteina [52, 53]. Aguti protein blokira receptore za melanokortin-4 i tako doprinosi progresu gojaznosti [54]. Aguti miševi su rezistentni na efekte leptina na sitost i na redukciju telesne težine [55] iako nemaju mutaciju u genu za leptinski receptor. Gojazni aguti miševi imaju viši arterijski pritisak od onih koji su mršavi [56]. Kod aguti miševa postoji kompenzatornka hiperleptinemija [55, 57] i nedavna studija je pokazala da povišena koncentracija leptina doprinosi povišenom arterijskom pritisku [57].

Povišen arterijski pritisak u stanju gojaznosti je praćen hiperleptinemijom koja može delimično poticati od simpatičkih presorskih efekata leptina [51]. Međutim, postavlja se pitanje kako povišene koncentracije leptina dovode do povišenog arterijskog pritiska ako su aguti miševi rezistentni na efekte leptina? [51] Da bi se ovo objasnilo nastao je koncept SLR [51]. Pretpostavlja se da su kod aguti miševa očuvana simpatoekscitatorski efekti leptina i pored rezistencije na efekte leptina koji obuhvataju sitost i redukciju telesne težine [51]. Correia i saradnici [58] su, u cilju potvrde ove pretpostavke, upoređivali efekte leptina na unošenje hrane, telesnu težinu i renalnu simpatičku nervnu aktivnost kod gojaznih aguti miševa u odnosu na "wild-type" mršave kontrolne miševe. Leptinom indukovano smanjenje unošenja hrane i telesne težine bilo je manje kod gojaznih aguti miševa nego kod mršavih kontrolnih miševa, ali je leptinom indukovano povećanje renalne simpatičke nervne aktivnosti u obe grupe bilo isto [58]. Ova pojava opadanja metaboličke aktivnosti (efekat na sitost i na redukciju telesne težine) i očuvanje simpatičkih efekata leptina takođe su zapaženi tokom cerebroventrikularne primene leptina u mozgu [59]. Dakle, pojava SLR kod aguti miševa odražava promene $\mathrm{u}$ centralnim nervnim putevima verovatno nishodno od receptora za leptin u hipotalamusu pošto receptor za leptin nema mutaciju kod aguti miševa [51].

Rahmouni i saradnici su izučavali gojaznošću izazvanu hipertenziju koristeći mišije modele Bardet-Biedl-ovog sindroma (BBS) [60], retkog oblika monogenske gojaznosti koja je često, mada ne uvek, praćena povećanjem krvnog pritiska [61]. Rahmouni i saradnici su u svojim istraživanjima koristili tri različita modela knockout BBS-miševa: knockout miševe za Bbs 2, Bbs4, odnosno Bbs6 gen. Sva tri modela su bili gojazni miševi sa hiperleptinemijom i rezistencijom na metaboličke efekte leptina [60]. Rezultati ispitivanja su pokazali da je kod dva modela sa ispoljenom SLR (knockout Bbs4 i Bbs 6) postojala leptinom izazvana neurogena hipertenzija, dok je kod trećeg modela (knockout Bbs2), pored gubitka metaboličkih efekata leptina, postojao i gubitak delovanja leptina na aktivnost simpatičkog nervnog sistema, stoga su ovi miševi imali normalan krvni pritisak [60]. Ovi rezultati su u skladu sa zapažanjima da se kod ljudi koji imaju mutacije u BBS 4 i BBS 6 genima javlja hipertenzija, za razliku od onih pacijenata kod kojih je mutirana BBS 2 varijanta gena [61]. 
Podudaranje karakteritičnih genotipova kod miševa i ljudi sa pojavom povišenog krvnog pritiska ukazuje na mogućnost da se hiperleptinemija praćena SLR verovatno javlja i kod ljudi [61]. Naime, većina gojaznih osoba ispoljava metaboličku rezistenciju na leptin i kompenzatornu hiperleptinemiju [62]. Međutim, dokazi koji bi podržali hipotezu o SLR kod ljudi su ograničeni na nekolicinu studija u kojima je ili korišćen mali broj ispitanika, ili su ispitivanja sprovođena na specifičnim populacionim podgrupama i nedovoljno su generalizovana $[63,64,65]$. Izvestan broj studija u kojima su kako gojazni, tako i ispitanici normalne telesne težine, izlagani bilo akutnom, bilo hroničnom tretmanu leptinom, nisu pokazala povećanje krvnog pritiska, što dovodi u pitanje ulogu leptina u regulaciji krvnog pritiska i patogenezi hipertenzije izazvane gojaznošću kod ljudi [66, 67, 68, 69].

Masuo i saradnici su, u svojoj studiji u kojoj su grupu ispitanika činili beli muškarci sa normalnim krvnim pritiskom i nešto višim indeksom telesne mase (engl. body mass index, BMI), zaključili da čak i neznatan gubitak funkcije leptinskog receptora smanjuje aktivnost simpatikusa kod ljudi [70]. Ovi rezultati se podudaraju sa rezultatima koji pokazuju da kod gojaznih $\mathrm{db} / \mathrm{db}$ miševa, sa mutacijama uzrokovanim nefunkcionalnim receptorom za leptin, nedostaje odgovor simpatičkog nervnog sistema na leptin [71]. Rosmond i saradnici su pokazali da je nekoliko polimorfizama u genu za leptinski receptor povezano sa značajnim razlikama u vrednosti krvnog pritiska kod muškaraca srednjih godina starosti [72]. Njihova istraživanja sugerišu da je leptin uključen u regulaciju krvnog pritiska preko leptinskog receptora, pri čemu je, u slučaju povećanja vrednosti BMI i nivoa leptina, krvni pritisak povišen samo kod onih subjekata sa najzastupljenijom varijantom gena za leptinski receptor [72]. Manje zastupljene varijante gena za leptinski receptor pružale su neku vrstu „zaštite“ od hipertenzije [72].

\section{MOLEKULARNi MEHANIZMI NASTANKA SLR}

Molekularni biološki mehanizmi fenomena SLR ostaju za sada nepoznati [51]. Postojanje različitih molekularnih puteva delovanja leptina, kao i različitih specifičnih delova mozga u kojima leptin ostvaruje svoje efekte, ukazuju na moguće mehanizme nastanka SLR. Ekspresija endogenog supresora signalizacije citokina 3 (engl. suppressor of cytokine signaling 3, SOCS3) inhibira fosforilaciju na tirozinu OB-R, na taj način obezbeđujući važan mehanizam povratne sprege za signalizaciju receptora na nivou transkripcije [30, 73]. Smatra se, takođe, da promene u ekspresiji SOCS3 leže u osnovi pojave rezistencije na leptin [74]. Iako je danas jasno da prekomerna ekspresija SOCS3 dovodi do inhibicije signalizacije pomoću intracelularnog domena OB-Rb i drugih receptora, još uvek nije pokazano da sam SOCS3 posreduje $\mathrm{u}$ inhibiciji povratne sprege signalizacije OB-Rb [30]. Ekspresija knockdown SOCS3 (ali ne SHP-2) posre- dovana interferencijom sa RNK (engl. RNA interference, $\mathrm{RNA}_{\mathrm{i}}$ ) povećava fosforilaciju tirozina JAK2 i STAT3 [75]. Moguće je da je inhibicija od Tyr985-nezavisne, Tyr1138-zavisne povratne sprege signalizacije ERK i verovatno JAK2, u vezi sa akumulacijom SOCS3, pri čemu dolazi do produžene stimulacije intracelularnog domena OB-Rb $[74,75]$. Predložen je model gde signalizacija STAT3 pomoću OB-Rb omogućava i efekte leptina na unošenje hrane i kontrolu telesne težine, a istovremeno posreduje i u inhibiciji povratne sprege signalizacije receptora tokom produžene stimulacije preko indukcije ekspresije SOCS3 [30]. Smatra se da učešće SOCS3 u mehanizmu negativne povratne sprege signalizacije leptina leži u osnovi nastanka rezistencije na leptin u odnosu na hiperleptinemiju zapaženu kod većine gojaznih slučajeva [47]. Značaj akumulacije SOCS3 indukovane $\mathrm{OB}-\mathrm{Rb}$ u osetljivosti na biološka dejstva hormona kasnije je pokazana činjenicom da nedostatak SOCS3 povećava senzitivnost na leptin i potvrđuje rezistenciju na hranom indukovanu gojaznost $[30,76,77]$.

Još jedan mogući molekularni mehanizam uspostavljanja leptinske rezistencije podrazumeva učešće proteina tirozin fosfataze 1B (engl. protein tyrosine phosphatase $1 B, \mathrm{PTP} 1 \mathrm{~B})$. Istraživanja su pokazala da PTP1B reguliše signalizaciju leptina vršeći direktnu i specifičnu defosforilaciju JAK2 i STAT3 [78]. Dodatno, izgleda da PTP1B reguliše ekspresiju gena zavisnu od leptina, s obzirom da je pokazano da prekomerna ekspresija PTP1B u ćelijskim linijama hipotalamusa smanjuje ekspresiju STAT3 iRNK [79]. In vivo studije na miševima deficijentnim u protein PTP1B pokazale su da ovi miševi imaju povećanu osetljivost na delovanje leptina koja se ogleda u povećanoj supresiji apetita i gubitku telesne težine [80]. Takođe, tkivo hipotalamusa PTP1B-deficijentnih miševa sadrži povećani nivo fosforilacije STAT3 izazvane leptinom [80]. Ipak, za razliku od SOCS3, u eksperimentalnim modelima gojaznosti nije pokazana disregulacija PTP1B u hipotalamusu [81].

\section{ZAKLJUČAK}

Mnogobrojni literaturni podacu ukazuju na veoma bitnu ulogu leptina, kako u normalnim, tako i u patofiziološkim stanjima. Dalja istraživanja u smeru izučavanja molekularnog mehanizma delovanja leptina, kao i mehanizama njegove regulacije, su neophodna kako bi se jasnije sagledali efekti njegovog delovanja u patofiziološkim stanjima.

\section{ZaHVALNica}

Ovaj rad je podržan projektom broj 173033 (E.R.I.) finansiranim od strane Ministarstva prosvete, nauke i tehnološkog razvoja. 


\section{Literatura}

1. Li, M. D. "Leptin and beyond: an odyssey to the central control of body weight." Yale J Biol Med, (2011) 84 (1): 1-7.

2. Flier, J. S. i Maratos-Flier, E. "Lasker lauds leptin." Cell (2010) 143 (1): 9-12.

3. Friedman, J. M. "A tale of two hormones." Nat Med (2010) 16 (10): 1100-1106.

4. Friedman, J. M. "Modern science versus the stigma of obesity." Nat Med (2004) 10 (6): 563-569.

5. Fei, H., et al. "Anatomic localization of alternatively spliced leptin receptors (Ob-R) in mouse brain and other tissues." Proc Natl Acad Sci USA (1997) 94 (13): 7001-7005.

6. Hetherington AW, R. S. "The relation of various hypothalamic lesions to adiposity in the rat." J Comp Neurol (1942) 76: 475.

7. Brobeck, J. R. "Mechanism of the development of obesity in animals with hypothalamic lesions." Physiol Rev (1946) 26 (4): 541-559.

8. Bray, G. A. i York, D. A. "Hypothalamic and genetic obesity in experimental animals: an autonomic and endocrine hypothesis." Physiol Rev (1979) 59 (3): 719-809.

9. Brobeck, J. R., Tepperman, J. i Long, C. N. “The Effect of Experimental Obesity upon Carbohydrate Metabolism." Yale J Biol Med (1943) 15 (6): 893-904.

10. Anand, B. K. i Brobeck, J. R. "Localization of a "feeding center" in the hypothalamus of the rat." Proc Soc Exp Biol Med (1951) 77 (2): 323-324.

11. Stellar, E. "The physiology of motivation." Psychol Rev (1954) 61 (1): 5-22.

12. Huang, X. F., et al. "Localization of leptin receptor mRNA expression in mouse brain." Neuroreport (1996) 7 (15-17): 2635-2638.

13. Couce, M. E., et al. "Localization of leptin receptor in the human brain.” Neuroendocrinology (1997) 66 (3): 145-150.

14. Mercer, J. G., et al. "Localization of leptin receptor mRNA and the long form splice variant $(\mathrm{Ob}-\mathrm{Rb})$ in mouse hypothalamus and adjacent brain regions by in situ hybridization." FEBS Lett (1996) 387 (2-3): 113-116.

15. Stephens, T. W., et al. "The role of neuropeptide $\mathrm{Y}$ in the antiobesity action of the obese gene product.” Nature (1995) 377 (6549): 530-532.

16. Horvath, T. L., Andrews, Z. B. i Diano, S. "Fuel utilization by hypothalamic neurons: roles for ROS." Trends Endocrinol Metab (2009) 20 (2): 78-87.

17. Diano, S. "New aspects of melanocortin signaling: a role for PRCP in alpha-MSH degradation." Front Neuroendocrinol (2011) 32 (1): 70-83.

18. Elias, C. F., et al. "Leptin differentially regulates NPY and POMC neurons projecting to the lateral hypothalamic area." Neuron (1999) 23 (4): 775-786.

19. Cowley, M. A., et al. "Leptin activates anorexigenic POMC neurons through a neural network in the arcuate nucleus." Nature (2001) 411 (6836): 480-484.

20. Horvath, T. L., et al. "Neuropeptide-Y innervation of beta-endorphin-containing cells in the rat mediobasal hypothalamus: a light and electron microscopic double immunostaining analysis." Endocrinology (1992) 131 (5): 2461-2467.

21. Horvath, T. L., Garcia-Segura, L. M. i Naftolin, F. "Control of gonadotropin feedback: the possible role of estrogen-induced hypothalamic synaptic plasticity." Gynecol Endocrinol (1997) 11 (2): 139-143.

22. Hinney, A., et al. "Several mutations in the melanocortin-4 receptor gene including a nonsense and a frameshift mutation associated with dominantly inherited obesity in humans." J Clin Endocrinol Metab (1999) 84 (4): 1483-1486.

23. Vaisse, C., et al. "Melanocortin- 4 receptor mutations are a frequent and heterogeneous cause of morbid obesity." J Clin Invest (2000) 106 (2): 253-262.

24. Pinto, S., et al. "Rapid rewiring of arcuate nucleus feeding circuits by leptin." Science "2004" 304 (5667): 110-115.

25. Zhang, F., et al. "Crystal structure of the obese protein leptin-E100." Nature (1997) 387 (6629): 206-209.

26. Zhang, Y., et al. "Positional cloning of the mouse obese gene and its human homologue." Nature (1994) 372 (6505): 425-432.

27. Peelman, F., et al. "Mapping of the leptin binding sites and design of a leptin antagonist." J Biol Chem (2004) 279 (39): 41038-41046.
28. Holm, L. i Sander, C. "Mapping the protein universe." Science (1996) 273 (5275): 595-603.

29. Zabeau, L., et al. "The ins and outs of leptin receptor activation." FEBS Lett (2003) 546 (1): 45-50.

30. Fruhbeck, G. "Intracellular signalling pathways activated by leptin." Biochem J (2006) 393 (Pt 1): 7-20.

31. Tartaglia, L.A., et al. "Identification and expression cloning of a leptin receptor, OB-R.” Cell (1995) 83 (7): 1263-1271.

32. Lee, G. H., et al. "Abnormal splicing of the leptin receptor in diabetic mice." Nature (1996) 379 (6566): 632-635.

33. Lollmann, B., et al. "Detection and quantification of the leptin receptor splice variants $\mathrm{Ob}-\mathrm{Ra}, \mathrm{b}$, and, e in different mouse tissues." Biochem Biophys Res Commun (1997) 238 (2): 648-652.

34. Tartaglia, L. A. "The leptin receptor." J Biol Chem (1997) 272 (10): 6093-6096.

35. Myers, M. G., Jr. "Leptin receptor signaling and the regulation of mammalian physiology." Recent Prog Horm Res (2004) 59: 287-304.

36. Bazan, J. F. "A novel family of growth factor receptors: a common binding domain in the growth hormone, prolactin, erythropoietin and IL-6 receptors, and the p75 IL-2 receptor beta-chain." Biochem Biophys Res Commun (1989) 164 (2): 788-795.

37. Hegyi, K., et al. "Leptin-induced signal transduction pathways." Cell Biol Int (2004) 28 (3): 159-169.

38. Bazan, J. F. "Structural design and molecular evolution of a cytokine receptor superfamily.” Proc Natl Acad Sci USA (1990) 87 (18): 6934-6938.

39. van Greevenbroek, M. M., Schalkwijk, C. G. i Stehouwer, C. D. "Obesity-associated low-grade inflammation in type 2 diabetes mellitus: causes and consequences." Neth J Med (2013) 71 (4): 174-187.

40. Abate, N., et al. "Relationships of generalized and regional adiposity to insulin sensitivity in men." J Clin Invest (1995) 96 (1): 88-98.

41. Wang, M. Y., et al. "A novel leptin receptor isoform in rat." FEBS Lett (1996) 392 (2): 87-90

42. Akira, S. "Functional roles of STAT family proteins: lessons from knockout mice." Stem Cells (1999) 17 (3): 138-146.

43. Rahmouni, K., Haynes, W. G., Morgan, D. A. i Mark, A. L. "Intracellular mechanisms involved in leptin regulation of sympathetic outflow." Hypertension (2003) 41: 763-767.

44. Rahmouni, K., Sigmund, C. D., Haynes, W. G. i Mark, A. L. "Mitogen activated protein kinase: a newly discovered mediator of selective leptin actions." Hypertension (2005) 46: 867.

45. Bates, S.H., Stearns, W. H., Dundon, T. A., Schubert, M., Tso, A.W., Wang, Y., et al. "STAT3 signalling is required for leptin regulation of energy balance but not reproduction." Nature (2003) 421: 856-859.

46. Bjorbaek, C., et al. "Divergent signaling capacities of the long and short isoforms of the leptin receptor." J Biol Chem (1997) 272 (51): 3268632695 .

47. Banks, A. S., et al. "Activation of downstream signals by the long form of the leptin receptor." J Biol Chem (2000) 275 (19): 14563-14572.

48. Bjorbaek, C., et al. "Divergent roles of SHP-2 in ERK activation by leptin receptors." J Biol Chem (2001) 276 (7): 4747-4755.

49. Frederich, R. C., et al. "Leptin levels reflect body lipid content in mice: evidence for diet-induced resistance to leptin action." Nat Med (1995) 1 (12): 1311-1314

50. Zhang, Y., et al. "Positional cloning of the mouse obese gene and its human homologue." Nature (1994) 372 (6505): 425-432.

51. Myers, M. G., Jr., et al. "Challenges and opportunities of defining clinical leptin resistance." Cell Metab (2012) 15 (2): 150-156.

52. Matarese, G., Moschos, S. i Mantzoros, C. S. "Leptin in immunology." I Immunol (2005) 174 (6): 3137-3142.

53. Patterson, C. M., et al. "Molecular mapping of mouse brain regions innervated by leptin receptor-expressing cells." Brain Res (2011) 1378: $18-28$

54. Scott, M. M., et al. "Leptin targets in the mouse brain." J Comp Neurol (2009) 514 (5): 518-532.

55. Stradecki, H. M. i Jaworski, D.M. "Hyperphagia and leptin resistance in tissue inhibitor of metalloproteinase-2 deficient mice." J Neuroendocrinol (2011) 23 (3): 269-281. 
56. Elmquist, J. K., et al. "Distributions of leptin receptor mRNA isoforms in the rat brain." J Comp Neurol (1998) 395 (4): 535-547.

57. Ducy, P., et al. "Leptin inhibits bone formation through a hypothalamic relay: a central control of bone mass." Cell (2000) 100 (2): 197-207.

58. Shimomura, I., et al. "Leptin reverses insulin resistance and diabetes mellitus in mice with congenital lipodystrophy." Nature (1999) 401 (6748): 73-76.

59. Oral, E. A., et al. "Leptin-replacement therapy for lipodystrophy." N Engl J Med (2002) 346 (8): 570-578

60. Rahmouni, K., Fath, M. A., Seo, S., et al. "Leptin resistance contributes to obesity and hypertension in mouse models of Bardet-Biedl syndrome." J Clin Invest (2008) 118: 1458-1467.

61. Moore, S. J., Green, J. S., Fan, Y., et al. "Clinical and genetic epidemiology of Bardet-Biedl syndrome in Newfoundland: A 22-year prospective, population-based, cohort study.” Am J Med Genet Part A (2005) 132A: 352-360.

62. Lofgren, P., Andersson, I., Adolfsson, B., et al. "Long-term prospective and controlled studies demonstrate adipose tissue hypercellularity and relative leptin defiiency in the postobese state." J Clin Endocrinol Metab (2005) 90 (11): 6207-6213.

63. Snitker, S., Pratley, R. E., et al. "Relationship between muscle sympathetic nerve activity and plasma leptin concentration." Obes Res (1997) 5: 338-340.

64. Eikelis, N., Schlaich, M., et al. "Interactions between leptin and the human sympathetic nervous system.” Hypertension (2003) 41: 1072 1079.

65. Grassi, G., Seravalle, G., Cattaneo, B. M., et al. "Sympathetic activation in obese normotensive subjects." Hypertension (1995) 25 (4 Pt 1): 560-563.

66. Heymsfield, S. B., Greenberg, A. S., Fujioka, K., et al. "Recombinant leptin for weight loss in obese and lean adults: a randomized, controlled, dose-escalation trial." JAMA (1999) 282: 1568-1575.

67. Zelissen, P. M., Stenlof, K., Lean, M. E., et al. "Effect of three treatment schedules of recombinant methionyl human leptin on body weight in obese adults: a randomized, placebo-controlled trial." Diabetes Obes Metab (2005) 7: 755-761.

68. Brook, R. D., Bard, R. L., Bodary, P. F., et al. "Blood pressure and vascular effects of leptin in humans." Metab Syndr Relat Disord (2007) 5: $270-274$.
69. Ebihara, K., Kusakabe, T., Hirata, M., et al. "Efficacy and safety of leptin-replacement therapy and possible mechanisms of leptin actions in patients with generalized lipodystrophy." J Clin Endocrinol Metab (2007) 92: 532-541.

70. Masuo, K., Straznicky, N.E., Lambert, G.W., et al. "Leptin-receptor polymorphisms relate to obesity through blunted leptin-mediated sympathetic nerve activation in a Caucasian male population." Hypertens Res (2008) 31: 1093-1100.

71. Rahmouni, K., Haynes, W. G., Morgan, D. A. i Mark, A. L. "Role of melanocortin-4 receptors in mediating renal sympathoactivation to leptin and insulin." J Neurosci (2003) 23: 5998-6004.

72. Rosmond, R., Chagnon, Y.C., Holm, G., et al. "Hypertension in obesity and the leptin receptor gene locus." J Clin Endocrinol Metab (2000) 85: 3126-3131

73. Bjorbak, C., et al. "SOCS3 mediates feedback inhibition of the leptin receptor via Tyr985.” J Biol Chem (2000) 275 (51): 40649-40657.

74. Munzberg, H. i Myers, M. G., Jr. "Molecular and anatomical determinants of central leptin resistance.” Nat Neurosci (2005) 8 (5): 566-570.

75. Dunn, S. L., et al. "Feedback inhibition of leptin receptor/Jak2 signaling via Tyr1138 of the leptin receptor and suppressor of cytokine signaling 3.” Mol Endocrinol (2005) 19 (4): 925-938.

76. Howard, J. K., et al. "Enhanced leptin sensitivity and attenuation of diet-induced obesity in mice with haploinsufficiency of Socs3." Nat Med (2004) 10 (7): 734-738

77. Mori, H., et al. "Socs 3 deficiency in the brain elevates leptin sensitivity and confers resistance to diet-induced obesity." Nat Med (2004) 10 (7): 739-743.

78. Lund, I.K., et al. "Mechanism of protein tyrosine phosphatase 1B-mediated inhibition of leptin signalling." J Mol Endocrinol (2005) 34 (2): 339-351.

79. Kaszubska, W., Falls, H. D., et al. "Protein tyrosine phosphatase 1B negatively regulates leptin signaling in a hypothalamic cell line.” Mol Cell Endocrinol (2002) 195 (1-2): 109-118.

80. Cheng, A., et al. "Attenuation of leptin action and regulation of obesity by protein tyrosine phosphatase 1B.” Dev Cell (2002) 2 (4): 497-503.

81. Munzberg, H. i Myers, M. G., Jr. "Molecular and anatomical determinants of central leptin resistance." Nat Neurosci (2005) 8 (5): 566-570. 